\title{
ASSESSMENT OF AGRO-ENVIRONMENTAL CHALLENGES AND POLICY RECOMMENDATIONS FOR SUSTAINABLE AGRO-ENVIRONMENTAL MANAGEMENT IN WEST AFRICA
}

\begin{abstract}
Abdou Gafarou Abdoulaye Bamoi ${ }^{1}$, Hasan Yılmaz ${ }^{1}$
Keywords: Agro-environmental challenges, agro-environmental indicators, agroenvironmental policy, sustainable agro-environmental management, West Africa

Abstract. The agricultural sector, indispensable in meeting the increasing demand for food, is the main user of natural resources. Agricultural production breeds significant environmental impacts and problems both within and outside farms or agricultural holdings. This situation increases the sensitivity of the agriculture to the risks that can cause serious economic losses. Thus, unless measures are taken to solve the environmental problems arising from agricultural production, the sustainability of agricultural production and food supply even less the achievement of food and agriculture-related sustainable development goals can be seriously threatened. However, these risks and losses can be mitigated through policy reform, institutional and technological innovations. In West Africa, more than $40 \%$ of water and land resources are used for agricultural production. This makes agroenvironment relations more important. This study has been carried out to reveal the major agro-environmental challenge in West Africa and to examine the current approaches and policies applied to solve these problems. In the study, data obtained from FAO agro-environmental indicators database were used as the main material. In this study, using a research methodology subdivided into two stages, the effects of agricultural activities on the environment were examined, analysed and interpreted by comparing the agro-environmental profiles of West African countries with other OECD countries based on agro-environmental indicators. Agroenvironmental policies applied to resolve agro-environmental problems in West African countries were reviewed and recommendations for sustainable agroenvironmental management and also a more efficient and environmentally friendly agricultural sector were formulated for sustainable agriculture and food supply.
\end{abstract}

\section{Introduction}

Although all human activities cause environmental problems, agriculture, which is always closely related to the environment, is a sector that has the power to significantly affect natural resources. In the agricultural sector, modern

${ }^{1}$ Department of Agricultural Economics, Faculty of Agricultural, University of Applied Sciences, 32260 Çünür/ISPARTA, TURKEY. Corresponding author; E-mail: hasanyilmaz@isparta.edu.tr 
production techniques and technologies have been developed to increase the efficiency of this sector and significant improvements have been recorded in the technology use and production level in agriculture. Technological developments in agriculture have brought environmental problems along with the increase in agricultural production (Parlakay et al., 2015). In other words, although this progress in the agricultural sector has led to increasing in production and productivity, the direct or indirect negative effects of agriculture on the environment have also appeared in several countries and even in developing countries where agriculture is not developed. Generally, the use of intensive agricultural inputs and intensive production to obtain higher yields are among the main reasons for the increase of environmental problems arising from agricultural activities. With the spread of modern agricultural practices, agro-environmental problems have increased in the world. On the other hand, agricultural production is an indispensable production branch in meeting the increasing demand for agricultural and food products with the increase of the population. However, efforts to increase agricultural production to meet the increasing demand for agricultural products bring about agro-environmental problems. Neither sustainable food supply nor sustainable development can be achieved unless the necessary measures are taken against emerging environmental problems. Environmental economists argue that governments should implement pollution prevention rather than clean-up policies, which have greater sanctioning power over pollution and the efficient use of natural resources. In this context, it is necessary to develop policies taking into account that pollution is a squandering, less pollution means more efficient production, and the costs of preventing pollution will be profitable in the long term (Yilmaz, 2005). In this sense, agriculture in West African countries although characterized by low mechanization and use of chemical inputs, far from an intensive production structure is considered the most important cause of environmental problems. In terms of the development level of agriculture in the region, there are large differences between countries, as well as agro-environmental problems in countries. This is important in the decision-making process and the choice of policies to be applied. Identifying agro-environmental problems, taking into account their long-term effects; will make an important contribution to the effectiveness and success of the policies to be implemented. Therefore, in this study, it is aimed to reveal environmental problems arising from agricultural production in West Africa, to examine the existing approaches and policies applied to solve these problems and to develop environmentally-friendly agricultural policy proposals for sustainable age-environmental management and agricultural production. 


\section{Materials and methods}

The main material of the study was the data obtained from the United Nations Food and Agriculture Organization (FAO) agricultural environmental indicators database. Regarding agro-environmental problems, a total of eight environmental indicators, including agricultural land, fertilizer, pesticides, soil, energy, water, air, and biodiversity, were used to explain the environmental performance and environmental trends of agriculture in West African countries. Besides, published sources, national and international databases, internet resources and research and articles were also used. A two-stage research method was used in the study. In the first stage, which is source search and compilation of data, the necessary information and literature were searched. In the analysis and synthesis phase, the data obtained in the first step were evaluated and analyzed from different angles.

\section{Agro-environment state in West Africa}

The indicators used in the analysis of environmental problems in agriculture play an important role in identifying, monitoring and analyzing the effects of problems and policies by providing basic and preliminary information. Therefore, it was considered useful to examine and interpret agricultural indicators related to the ecosystem to understand the agro-environment state before moving on to agroenvironmental issues. For this purpose, Table 1 presents information on agroenvironmental indicators for West African countries. Also, to compare the agroenvironmental indicators of West African countries with other countries and to determine the situation of West African countries in terms of agro-environmental indicators, information on agro-environmental indicators for some selected OECD countries is given in Table 2 .

Cultivated land in the West African region accounts for $35.67 \%$ of the total arable agricultural land in the region (FAO, 2019). Outside Guinea, Guinea Bissau, Mali, and Mauritania; in the other countries of the region cultivated agricultural land is higher than the regional average of cultivated land. Compared to some of the major OECD countries examined in the study, in all countries except Australia and Mexico, the share of cultivated land is above the average for the West Africa region. Among the OECD countries, Finland has the highest rate of agricultural land cultivated with $98.86 \%$, while Australia has the lowest rate with $12.5 \%$ of cultivated land (Table 2). Although the average share of cultivated agricultural land (35.67\%) in West Africa is well below the EU average (64.6\%); it is nevertheless higher than the world average rate $(32.71 \%)$, the average rate of less developed countries (24.71\%) and the average rate of Africa (23.98\%) of cultivated land. This 
explains the possibility and the high probability of encountering environmental problems originating from agricultural production in West Africa. However, to determine the negative effects of agriculture on the environment, it is necessary to take into account the number of inputs used in production. The average quantities of chemical fertilizers and pesticides used per unit area in agricultura production in West Africa were calculated at $9.63 \mathrm{~kg} / \mathrm{ha}$ and $0.04 \mathrm{~kg} / \mathrm{ha}$, respectively. These values are quite low compared to the average quantity in the African continent, in the less developed countries, in the EU, and the world. The amount of chemical fertilizer used in the OECD countries examined is greater than $50 \mathrm{~kg} / \mathrm{ha}$ (Table 2). Belgium is the country that uses the most chemical fertilizer at $310 \mathrm{~kg} / \mathrm{ha}$; while the amount of fertilizer per unit area in Germany, Denmark, France, the Netherlands, the United Kingdom, and the United States is higher than the world average $(122.84 \mathrm{~kg} / \mathrm{ha})$.

Pesticide use per unit area exceeds $1 \mathrm{~kg} / \mathrm{ha}$ in all OECD countries except Finland. Germany, Belgium, the United States, France, Italy, the Netherlands, and the United Kingdom use pesticides above the world average $(2.57 \mathrm{~kg} / \mathrm{ha})$ per unit area. The use of chemical fertilizers and pesticides is well below these values in West African countries. This indicates that the region has not reached a sufficiently critical level of environmental pollution caused by pesticides and chemical fertilizers. If agricultural chemicals used properly or in an appropriate manner, they also can contribute to the rural environment and sustainable regional rural development. Also, the sustainable use of agricultural chemicals contributes to further risk reduction. In order to achieve a sustainable farm, farmers need to focus on agricultural techniques that support the health of the environment (Yilmaz, 2018). Concerning energy consumption in agriculture, a situation similar to the use of pesticides and chemical fertilizers appears. Although there is no data on energy use for agricultural production in most countries in the region, the average energy use rate for agricultural production in the region is $0.13 \%$; in short only $0.13 \%$ of the total amount of energy used is consumed in agriculture. The average rate of energy use in agriculture in Africa, the less developed countries, the EU and the world is respectively $1.98 \%, 1.89 \%, 2.16 \%$, and $2.07 \%$. In the United States and all OECD countries except Germany and the United Kingdom, the energy use rate for agricultural production is higher than in West Africa and the world average. Among the OECD countries studied, Turkey is the country where the energy use rate for agricultural production is highest with $6.46 \%$. It can be said that because of the low rate of energy use for agricultural production in West African countries, no 


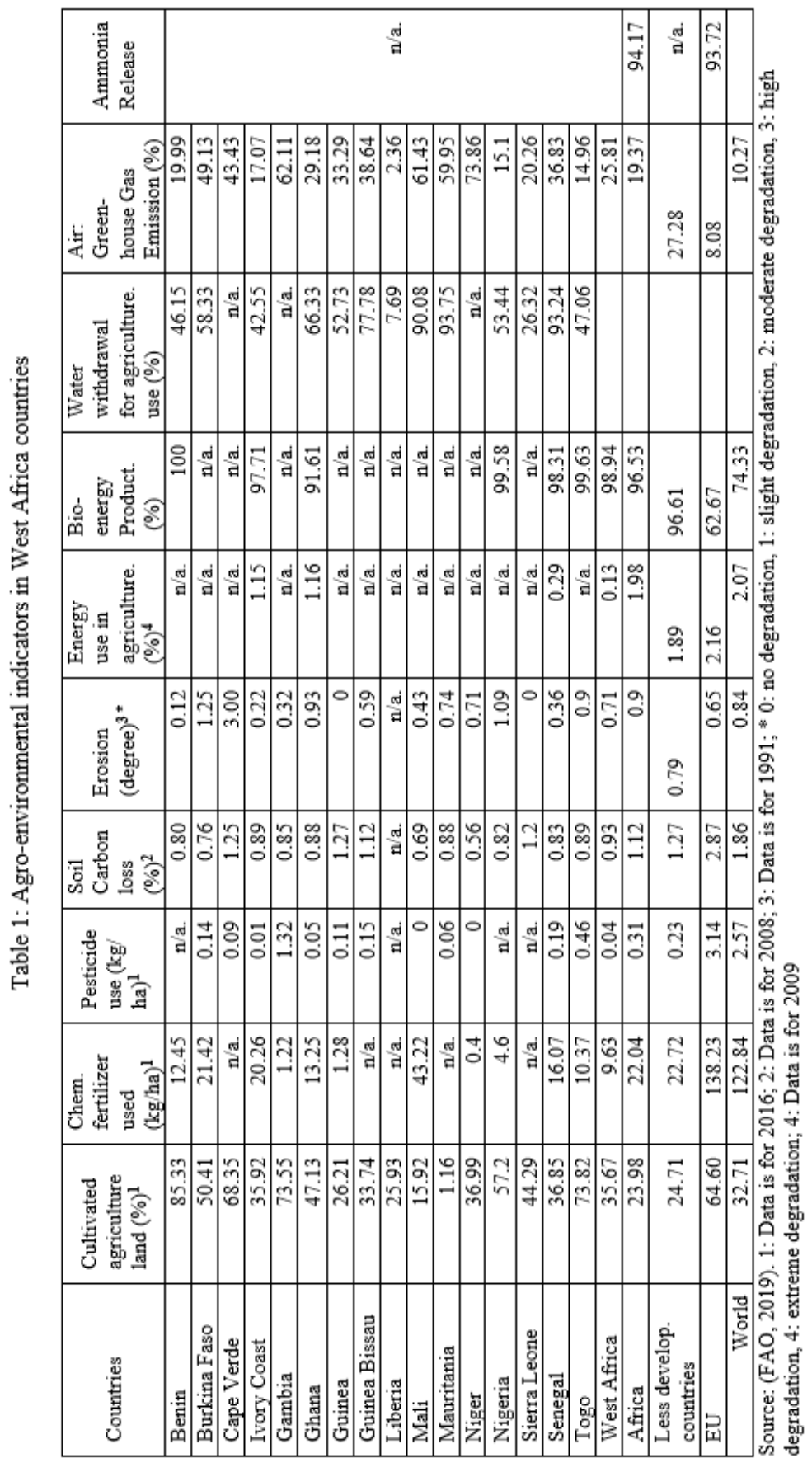




\begin{tabular}{|c|c|c|c|c|c|c|c|c|c|c|c|c|c|c|c|c|}
\hline 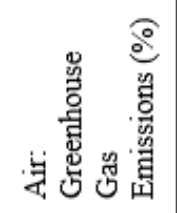 & $\vec{~} \vec{~}$ & $\begin{array}{l}J \\
\text { i } \\
\mathrm{i}\end{array}$ & ڤ̂. & $\begin{array}{l}\vec{E} \\
\dot{J}\end{array}$ & $\begin{array}{c}\vec{m} \\
\stackrel{n}{n}\end{array}$ & $\begin{array}{l}n \\
\stackrel{\sigma}{\sigma}\end{array}$ & $\begin{array}{l}0 \\
0 \\
0 \\
0\end{array}$ & 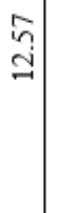 & \begin{tabular}{l}
8 \\
\hdashline \\
$\infty$
\end{tabular} & $\stackrel{9}{7}$ & $\begin{array}{l}0 \\
\infty \\
\infty \\
\infty\end{array}$ & 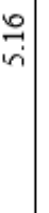 & $\begin{array}{l}\overrightarrow{0} \\
\text { cे } \\
\end{array}$ & ஸे & $\begin{array}{lll}\infty & \\
\infty \\
\infty \\
\infty\end{array}$ & సิ \\
\hline 焉惫 & ๙ุ. & $\mid \begin{array}{c}\infty \\
2 \\
\\
\end{array}$ & $\begin{array}{l}\text { t } \\
0 \\
0\end{array}$ & 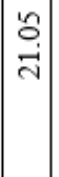 & $\begin{array}{c}\hat{0} \\
\dot{m}\end{array}$ & $\begin{array}{l}\text { ㅁ } \\
\text { a }\end{array}$ & $\begin{array}{l}\hat{0} \\
\dot{y}\end{array}$ & $\begin{array}{l}\stackrel{1}{\circ} \\
\circ\end{array}$ & $\begin{array}{l}\overrightarrow{0} \\
0\end{array}$ & 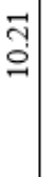 & 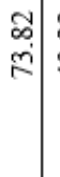 & 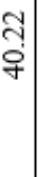 & & & & \\
\hline 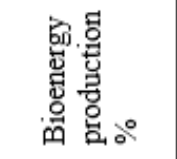 & $\begin{array}{l}0 \\
0 \\
0\end{array}$ & $\begin{array}{l}8 \\
\vdots \\
\infty \\
2\end{array}$ & $\begin{array}{l}\text { 우 } \\
\therefore \\
5\end{array}$ & $\mid \begin{array}{c}n \\
\infty \\
\infty \\
n\end{array}$ & $\begin{array}{l}\text { సे } \\
\vdots \\
\vdots\end{array}$ & $\begin{array}{l}\text { 염 } \\
\text { : }\end{array}$ & $\begin{array}{c}\text { กे } \\
\text { กे }\end{array}$ & $\begin{array}{l}\text { ñ } \\
\text { in }\end{array}$ & $\begin{array}{l}7 \\
0 \\
0 \\
n\end{array}$ & 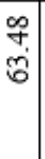 & \begin{tabular}{l|}
$\overrightarrow{0}$ \\
0 \\
0
\end{tabular} & 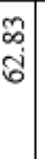 & $\begin{array}{l}\text { J } \\
\alpha \\
\alpha\end{array}$ & $\begin{array}{l}\tilde{n} \\
2 \\
2\end{array}$ & 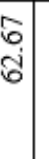 & \begin{tabular}{l} 
m \\
\multirow{Z}{Z}{}
\end{tabular} \\
\hline 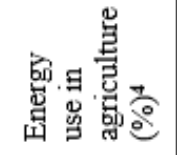 & 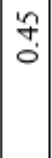 & $\begin{array}{l}2 \\
2 \\
i\end{array}$ & $\stackrel{\Delta}{i}$ & $\begin{array}{l}\infty \\
2 \\
+\end{array}$ & $\vec{m}$ & तి & $\begin{array}{l}J \\
i \\
i\end{array}$ & $\overrightarrow{\text { ले }}$ & $\begin{array}{c}\overrightarrow{7} \\
\vec{v}\end{array}$ & $\begin{array}{l}\text { t. } \\
0 \\
0\end{array}$ & $\mid \begin{array}{l}0 \\
0 \\
1 \\
0\end{array}$ & \begin{tabular}{c}
0 \\
\hdashline \\
0
\end{tabular} & $\frac{m}{0}$ & $\stackrel{\infty}{\mathscr{్}}$ & 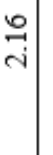 & ¿े \\
\hline 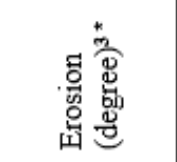 & $\begin{array}{l}\infty \\
\stackrel{\infty}{0} \\
0\end{array}$ & $\begin{array}{l}8 \\
\\
\end{array}$ & d & 0 & $\begin{array}{l} \\
\\
\end{array}$ & $\begin{array}{l}9 \\
0 \\
0\end{array}$ & $\stackrel{\infty}{=}$ & \begin{tabular}{|c|}
0 \\
0 \\
-1
\end{tabular} & $\stackrel{n}{a}$ & $\hat{\imath}$ & \begin{tabular}{l|} 
\\
$\stackrel{2}{ }$ \\
-
\end{tabular} & \begin{tabular}{|c|} 
\\
$\infty$ \\
$\dot{0}$
\end{tabular} & $\vec{E}$ & $\begin{array}{l}\text { oे } \\
\text { o }\end{array}$ & :م & \$. \\
\hline 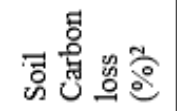 & 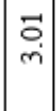 & $\mid \begin{array}{l}\hat{0} \\
0\end{array}$ & ભె & ले & 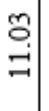 & $\underset{f}{\mathcal{I}}$ & 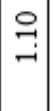 & $\begin{array}{c}\overrightarrow{0} \\
\dot{m}\end{array}$ & ڤ్. & 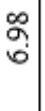 & 吕 & กี & ڤ̆ & $\stackrel{\exists}{\exists}$ & ๙ీ & $\stackrel{\circ}{\stackrel{一}{-}}$ \\
\hline 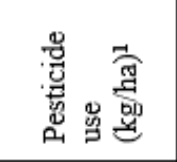 & $\begin{array}{l}\sigma \\
\bar{n}\end{array}$ & 을 & $\begin{array}{l}0 \\
0 \\
0 \\
0\end{array}$ & $\exists$ & $\begin{array}{l}\stackrel{2}{\circ} \\
\vdots\end{array}$ & $\begin{array}{c}A \\
\text { mi }\end{array}$ & $\begin{array}{l}8 \\
0 \\
0\end{array}$ & $\mid \begin{array}{c}\infty \\
-\infty\end{array}$ & $\begin{array}{c}\infty \\
\grave{m}\end{array}$ & $\stackrel{\vec{m}}{m}$ & $\vec{a}$ & $\begin{array}{l}n \\
\stackrel{n}{2}\end{array}$ & : & ले. & $\begin{array}{c} \pm \\
\stackrel{m}{m}\end{array}$ & $\sqrt[n]{2}$ \\
\hline 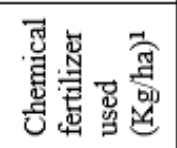 & 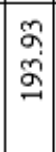 & \begin{tabular}{|c|}
$\tilde{6}$ \\
$\hat{6}$
\end{tabular} & 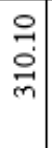 & \begin{tabular}{|c|} 
\\
\\
\\
\end{tabular} & $\begin{array}{l}\text { o } \\
\text { वे. } \\
\infty\end{array}$ & 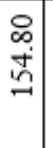 & 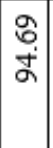 & 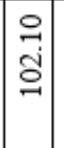 & 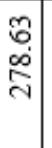 & 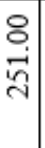 & \begin{tabular}{|c|} 
\\
$q$ \\
$\infty$ \\
$ٍ$ \\
$\ddots$
\end{tabular} & 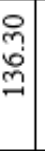 & $\begin{array}{c}0 \\
\vdots \\
\alpha\end{array}$ & $\begin{array}{l}\text { ठे } \\
\text { ते }\end{array}$ & 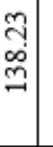 & 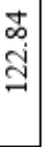 \\
\hline 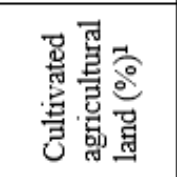 & $\begin{array}{l}\alpha \\
\stackrel{\infty}{i} \\
\end{array}$ & 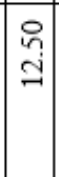 & $\begin{array}{l}\infty \\
0 \\
\dot{0}\end{array}$ & \begin{tabular}{|c|}
$\tilde{m}$ \\
$\bar{a}$
\end{tabular} & $\begin{array}{l}\circ \\
\infty \\
\infty\end{array}$ & $\begin{array}{l}\hat{m} \\
\hat{0}\end{array}$ & 곡 & $\begin{array}{l}\vec{A} \\
\text { n่ }\end{array}$ & $\begin{array}{l}m \\
m \\
n \\
n\end{array}$ & $\begin{array}{l}8 \\
8 \\
\dot{m} \\
m\end{array}$ & \begin{tabular}{|l|} 
\\
\\
\end{tabular} & $\begin{array}{c}0 \\
\substack{0 \\
m \\
m} \\
m\end{array}$ & 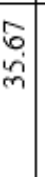 & 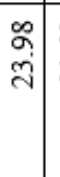 & $\begin{array}{l}8 \\
\text { +0 }\end{array}$ & $\begin{array}{c}\vec{i} \\
\text { in } \\
\end{array}$ \\
\hline 密 & 莕 & 昜 & 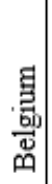 & 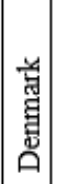 & 帘 & 营 & 垔 & 荵 & 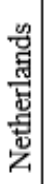 & 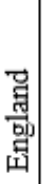 & 窇 & 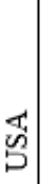 & 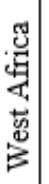 & 敂 & ? 学 & 훔 \\
\hline
\end{tabular}


agricultural environmental problems are arising from energy consumption for agricultural production in the region. It should also be noted that $98.94 \%$ of bioenergy production in West Africa is of agricultural origin. It can, therefore, be said that bioenergy production in the region is produced solely from agriculture. On the other hand, in the OECD countries evaluated in this study except for Italy and Turkey, bioenergy produced from agriculture is more than $50 \%$ of the total renewable energy production. The water use, an important factor in agricultural production, was also examined in this study. In all West African countries, except for Liberia and Sierra Leone, the water used for agricultural production constitutes more than $40 \%$ of the total amount of water used. In the region, since agricultural production depends largely on rainfall, this can be explained by the high precipitation and underdevelopment of other industrial sectors. Except for Australia, Mexico, Turkey, and the United States; in the OECD countries considered in this study, the rate of agricultural water withdrawals is above $40 \%$. In Germany, Belgium, and the Netherlands this percentage is less than $1 \%$.

Another important indicator for the agricultural environment is the soil organic carbon value, which explains whether soils are in good condition. This value indicates that soils with an organic carbon content of less than $1 \%$ are affected by destruction and erosion and that soils with an organic carbon content between $1 \%$ and $10 \%$ have a high agricultural potential (FAO, 2019). As Table 1 shows, there is no loss of soil organic carbon in countries such as Cape Verde, Guinea, Guinea Bissau, and Sierra Leone. In other West African countries other than these countries, soil organic carbon loss is less than $1 \%$. This shows that the soil in West Africa is affected by destruction and erosion. At the same time, among the OECD countries analyzed, only in Australia and Turkey are land affected by destruction and erosion. It should also be emphasized that according to the results of the Global Assessment of Human-Induced Soil Degradation, there is slight soils degradation in the region.

In contrast, in the OECD countries examined only in Italy, Mexico and Turkey it can be said that there is slight and moderate soil degradation. The degree of erosion varies between 1 and 2 in these countries (Table 2). Although there is no up-to-date data, it is possible to say that erosion and soil degradation is one of the major agro-environmental problems because of the intensive farming techniques that are used in these countries to obtain high yields per unit area and because of inadequate and inappropriate methods of soil cultivation.

Analysis of agricultural greenhouse gas emissions and ammonia emissions indicators showing air pollution from agricultural production indicates that the rate of agricultural GHGs in the region is higher than the average agricultural GHG rate in Africa, in the EU and the world (Table 1). In West African countries, the GHG rate from agricultural production is lower in Liberia, at $2.36 \%$ and above the world 
average $(10.27 \%)$ in all other West African countries. In the OECD countries examined, the GHG rate from agriculture is below $15 \%$ and above the world average in Australia, Denmark, France and Mexico (Table 2). Based on this indicator, it can be confirmed that there is a significant environmental problem in terms of agricultural GHG in the region.

On the other hand, indicators of genetic diversity, species diversity and ecosystem diversity are considered important indicators of agricultural biodiversity in terms of agro-environmental relationships (OCED, 2001). These indicators explain the link and the situation between agriculture and biodiversity. However, in this study, agricultural biodiversity (diversity of genes, species, and ecosystems) could not be examined due to the lack of data on these indicators.

\section{Major agro-environmental challenges in West Africa}

According to the USAID West Africa office's report on the West Africa Environmental Threats and Opportunities Assessment, the state of the West Africa environment is not good. Each of its ecosystems is at serious risk, mainly from anthropogenic causes, but also from climatic changes that already affect livelihoods of the region's populations (USAID, 2013). In addition to this as the food needs of the increasing population in the world cause important changes in agriculture, efforts to provide food supply to meet the increasing food demand along with the population increase in the West African region and efforts to increase cotton production, which is the main income source of the region's economy, have brought some new developments in agricultural production as well as negative effects on the environment. The conversion of natural and green areas to agricultural land, excessive use of inputs, excessive rainfall and the unconscious water use are the main causes of environmental problems arising from agricultural activity (Vergez, 2011). Also, the negative effects of chemical inputs used in the production process on the ecosystem are not negligible and should be considered. In West African countries, efforts to extend or expand natural and green areas to farmland or into agricultural lands have increased the direct or indirect negative impacts of agriculture on the environment. For example, in cotton-growing countries in West Africa, increasing cotton production areas due to the encouragement and support of cotton production by governments to increase the income sources of national economies have negative environmental consequences such as climate change, biodiversity loss and accelerating desertification (Abba et al., 2006). Moreover, based on the agro-environmental indicators examined in Table 1, deforestation, soil degradation and desertification, water pollution, air pollution by agricultural greenhouse gas emissions (GHG), climate change and 
degradation of agricultural biodiversity can be listed as important agroenvironmental challenges in West African countries.

\subsection{Deforestation}

Deforestation involves forest conversion to land used for other activities sector. To meet other land needs including mining of minerals, agriculture (including tree crops), and pasture land for cattle, the natural forests were destroyed. Specifically, in agricultural context forests destruction in West African countries results mainly from the extension of cultivated land and the transformation of forests into agricultural areas. To increase cultivated land in West Africa, agricultural production, which is a major land user, has caused significant deforestation. During the period 1990-2000, the region recorded the highest deforestation rate in the world with 1,255,000 hectares of forest loss and $1.7 \%$ of deforestation rate per year (FAO, 2019). This can be explained by the purchase of very tracts of land to produce planting and other crops by local and foreign companies in many West African countries (USAID, 2013) and on the other hand, the population growth associated with the growing food demand contributing to the conversion of forests, rangeland and, woodlands to cropland. In West Africa, the extension of agricultural areas by forest destruction threatens forest resources yet given the indispensability and contribution of forests to the provision of food, water, clean air and, shelter; their protections, conservations, and sustainable use thus become an indisputable human duty. Therefore, implement land tenure security measures and forest regulation and protection should be taken to reverse the trend in the deforestation.

\subsection{Degradation of soil and land, desertification}

Caused by human drivers including grazing pressure, expanding agriculture, agricultural practices, forest management as well climate drivers comprising extreme temperatures, extreme rainfall, reduced rates of carbon uptake and reduced capacity of ecosystems to act as carbon sinks into the future (IPCC, 2019); land degradation and desertification is one of the most important agro-environmental challenges in West African countries. This severe problem endangering the sustainability of traditional agricultural production systems, rages in the region and in particular in the Sahel countries (Senegal, Mauritania, Mali, Burkina Faso, and Nigeria). This is leaned and justified by the analysis and interpretation of the erosion and soil organic carbon loss indicators done in the first part of the study based on FAO data. In the region, all of them both land degradation and as desertification drivers (human and climate) are observed. Mainly deforestation, erosion of agricultural soil, cropland expansion, unsustainable land management practices including poor agricultural practices, wrong land use, inappropriate and 
wrong tillage techniques and overgrazing by livestock, and land salinization are the drivers of this major environmental challenges of West African agriculture. Moreover, for years the growing soil fertility crisis has worsened in the region and in particular in cotton producer countries due to the increase in productivity per hectare and land degradation (ECOWAS, 2015). The intensive monoculture of cotton thus contributes to the amplification of soil degradation problems in the region. About desertification, which represents all forms and levels of land degradation occurring in drylands (IPCC, 2019); is observed in dry and arid zones of the West African region. According to the geographical distribution of drylands, delimited based on the Aridity Index, desertification is observed in Nigeria, Niger, Burkina Faso, Mali, Mauritania, and Senegal. Resulting from many factors, including human activities and climatic variations, the range and intensity of desertification have increased in some arid areas during the last 6 decades (IPCC, $2019)$. Drylands currently cover about $46.2 \%( \pm 0.8 \%)$ of the 7 global land areas and are home to 3 billion people (IPCC, 2019).

While recalling that soil is a non-renewable resource, that food and nutrition security is fundamentally based on healthy soils that are the basis of food systems, it would be extremely relevant to emphasize that the preservation of this valuable resource is essential for a healthy and sustainable food system and diet. For that, actions to address land degradation are key facing on agro-environmental challenges. These actions, which the most important are agronomic soil management measures; agroforestry; sustainable land management including croplivestock association and interaction, integrated management, and the use of local and indigenous knowledge in land management; sustainable forest management comprising reducing deforestation, forest degradation and increasing afforestation; and policy betterment on land degradation (IPCC, 2019); must be rigorously implemented and promoted at all levels of agricultural interventions. In this sense, it is imperious to assess the success level of current land degradation management approaches and soil defense and restoration methods that being implemented and rethink land management in an agricultural sector based on identifying potential solutions and sustainable land management practices adapted and applicable according to the real causes of land degradation and agro-ecological characteristics of each country of the region.

\subsection{Water pollution}

Usually, as a result of human activities, water pollution is the contamination of bodies of water, such as lakes, rivers, seas, the oceans, aquifers as well as groundwater. Occurring when pollutants reach these bodies of water, without treatment; water pollution is a problem for the existing species and ecosystems, nowadays it is becoming one of the main global environmental challenges. Various 
human activities, including agriculture, industry, handicrafts, mining activities, certain fishing practices, and household waste also lead to deterioration of water quality (UEMOA, 2008). Not to mention other factors like urbanization, energy use, damming of rivers, destruction of wetlands, deforestation and forest destruction that also contribute to water pollution. These different sources of pollution expose water sources to contamination and give rise to biodiversity loss, soil quality deterioration, acidification, and global warming. This study based specifically on agro-environmental challenges, the next explanation in this part is exclusively related to agricultural causes, that is to say, the causes originated in agricultural production.

Indeed, agricultural pressures on water quality come from cropping and livestock systems and aquaculture, which have all expanded and intensified in both developed and developing countries (FAO and IWMI, 2017). The crop production, mainly through the intensive use of inputs such as pesticides, chemical fertilizers, and irrigation poses agricultural water pollution. The associated waste of livestock, including manure; new agricultural pollutants from veterinary medicines (antibiotics, vaccines and growth promoters), zoonotic waterborne pathogens and fish excreta and uneaten feeds from fed aquaculture have serious implications for water quality (FAO and IWMI, 2017). Besides, in West Africa water pollution from agricultural production generally arises from the following causes (UEMOA, 2008):

- Misuse and mismanagement of pesticides and chemical fertilizers (especially in cotton production);

- Storage and use of old pesticides and chemical fertilizers (usually prohibited or expired);

- Non-draining of drainage water from irrigated areas;

- Inadequate agricultural production practices causing erosion.

However, it should also be noted that the extent of the problem of water pollution by agriculture and its causes are dissimilar in the region depending on the prevalence of farming systems and practices. For that having regard to the water pollution negative impacts on human health and productive activities including agriculture, it necessitates to analyze the current state of water pollution in agriculture and enhance the agricultural water management strategies according to the study results in each country or region.

\subsection{Greenhouse gas emissions}

Greenhouse gases are one of the most important causes of global warming. According to FAO, the livestock sector alone accounts for $14.5 \%$ of greenhouse gases. With regard to greenhouse gas emissions, $9 \%$ of carbon dioxide $(\mathrm{CO} 2), 37 \%$ of methane $(\mathrm{CH} 4)$ and $65 \%$ of nitrogen oxides (N20) originate from animal 
production (OECD, 2008). Carbon dioxide emissions are mainly due to deforestation (expansion of cultivated areas and pastures), while methane emissions, which have an impact 23 times higher than $\mathrm{CO} 2$ on global warming, are mainly due to gastric fermentation of ruminants and manure management $(74 \%$ and $21 \%$ respectively). For nitrogen oxide emissions, which have a global warming potential of approximately 300 times higher than $\mathrm{CO} 2$, are mainly caused by fertilizers, particularly nitrogen fertilizers and slurry (OECD, 2008). In other saying agricultural greenhouse gas emissions come from several sources as agricultural soil management, enteric fermentation, manure management, and forest land and grassland management.

In fact, in West Africa, $25 \%$ of greenhouse gas emissions come from agricultural production (Table 1). As shown in Table 1, this percentage is above $35 \%$ in the Sahel countries of the region except for Nigeria. This high rate of agricultural greenhouse gas emissions could imply the size of this environmental challenge in the region. In West Africa, excessive amounts of chemical fertilizers and nitrogen products used in intensive cotton production, animal production characterized by livestock and small ruminants, and largely increasing deforestation are the main sources of agricultural greenhouse gas emissions. Thereby, although efficient agricultural practices are key need to reduce GHG, each of the causes should be examined along with possible ways of reducing agricultural emissions.

Finally, due to the lack of data on agricultural ammonia emissions in West Africa, the effects of ammonia emissions on agro-environmental issues were not addressed in this study.

\subsection{Climate change}

At the same time perceived as a consequence first and subsequently all across its contributory effect, one of the causes of global warming, climate change is the world's biggest environmental challenge of ecological and environmental current events. This issue severely influencing the physical, biological and human systems poses many risks for ecosystems and agro-ecosystems, food systems, incomes and trade, livelihoods, and all four dimensions of food security (FAO, 2017). The main cause of climate change is global warming, circuitously greenhouse gas which arises from many human activities sector as so agriculture. According to FAO, GHG emissions from agriculture (crops and livestock), forestry and other land uses the amount to 21 percent of total global GHG emissions.

Otherwise, in the West African region, the high greenhouse gas emissions and deforestation resulting from the expansion of cultivated land contributes significantly to climate change. As mentioned above, greenhouse gas emissions from agriculture are high in the region, accounting for $25 \%$ of total greenhouse gas 
emissions. Trees that are essential for climate regulation by absorbing carbon dioxide (CO2) from the atmosphere are also greatly reduced due to deforestation. In the region, $30 \%$ of the $\mathrm{CO} 2$ emitted is due to deforestation, grassland and forest fires (UEMOA, 2008). In West Africa, climate change leads to high fluctuations in precipitation (decline in rainfall, severe drought, and frequent floods). Varying according to the countries of the region, annual rainfall has decreased from $10 \%$ to $30 \%$ (UEMOA, 2008). Given the direct effects of climate change on agricultural production and food security; the policymakers in partnership with the stakeholders of the agricultural sector have the obligation to orientate the public and peasant actions in the fight against its causes as much as possible, as well as on the adaptation to climate changes. Particularly in west African countries, although studies are underway to reduce the causes of climate change and adapt production systems and existence of many climate changes related farmer education such as farmer field school that aims the integrating climate resilience into the agricultural sector for food security in rural; the development and strengthening of action research programs and national and regional policy frameworks on climate change is still a crucial need for the identifying of better adaptation and building resilience strategies to climate change and climate-smart management of agroecosystems (including land, forest, water, and biodiversity).

\subsection{Destruction of agricultural biodiversity}

The combined effect of inappropriate farming practices in West African countries is increasingly resulting in loss of biodiversity. There is a wide range of agricultural practices in the region that contribute to the destruction of biodiversity

- These are the following:

- Strong use of genetically modified organisms better adapted to climate change or reduction of precipitation time;

- Misuse and overuse of pesticides and chemical fertilizers in cotton farming;

- Deforestation, destruction of tree resources to expand cultivated areas;

- Degradation of pasture resources due to overgrazing and unsustainable methods and techniques of grazing;

- GHG emissions from agricultural production (the main cause of global warming and species extinction);

- Bush, grass and forest fires.

It should be emphasized that in the region the lack of farmers' knowledge about biodiversity and their low level of knowledge about the contribution of biodiversity to the environmental products and services of national economies also contribute to the loss of biodiversity.

Additionally, as agricultural biodiversity is vital to cope with climate change and ensure the future of food security, the urgent adoption and implementation of 
protective and sustainable measures for the development and conservative use of this biodiversity become imperatively unavoidable.

\section{Agro-environmental policy in west africa}

Addressing the negative effects of agriculture on the environment in agricultural policymaking has become an inescapable necessity to reduce agroenvironmental problems and ensure sustainable agricultural production worldwide. Nowadays, the importance and the evolution revealed by this consideration of the effects of agriculture on the environment during all phases of agricultural policies (from policy conception to policy evaluation) led to the emergence of agroenvironmental policies. Today, the importance of agro-environmental policies is increasing and its policies are booming with new regulations. In the context of agro-environment policy, the objective in this part of the study is to evaluate environmental laws and agro-environmental policy instruments, as well as regulations on agriculture and environment relations, agro-environmental management and then environmental relationships implemented in West African countries at regional and national levels. This assessment places special emphasis on sustainable agricultural production techniques, environmentally friendly agricultural production techniques implemented in the region. As a result of leaflets and research, as in developed countries in West African countries, there are no agro-environmental policies under implementation or any initiative to develop agro-environmental policies. Nevertheless, the Department of Agriculture, Environment and Water Resources of the Economic Community of West African States (ECOWAS) have developed a regional policy for each of these three sectors, including respectively agricultural policy, environmental policy and water resources policy (IUCN, 2008). To determine the policies to be applied to solve environmental problems originating from agricultural in the region, the ECOWAS common regional agricultural policy was examined in terms of the environment and ECOWAS common regional environmental policy was also examined in terms of the agricultural sector. As a result of the analysis and assessments, recommendations have been developed to identify elements of a common agroenvironmental policy to be implemented in West Africa $\mathrm{n}$ countries.

\subsection{West Africa's common agricultural policy and the environment}

The regional agricultural policy of West Africa was examined to identify the links between agriculture and the environment highlighted in the said policy. To this end, the strategies, instruments/tools, and measures of the agricultural policy included in the regional agricultural policy and implemented in the region to limit the negative impacts of agriculture on the environment and increase positive 
impacts on the environment have been analyzed. One of the main objectives of the ECOWAS Common Agricultural Policy is to ensure the rational use and protection of common resources (ECOWAS, 2015). To achieve this goal, responsible use for the protection and conservation of natural resources and the achievement of increased agricultural production through the rational use of production systems adapted to different agro-ecological environments have been identified as specific priorities of regional policy (RECA, 2019). On the other hand, a careful study of the pillars of the policy (regional integration of agricultural products and markets, opening of regional agriculture to international markets, regional and technical cooperation) and intervention areas of regional policy (increase of productivity and competitiveness of agriculture, application of the trade regime between countries, adaptation of the common external foreign trade regime) (ECOWAS, 2004), make it possible to affirm that agro-environmental problems are not included in the pillars of policy or the policy intervention areas. However, although in the implementation of the regional agricultural policy there are regional programs for the water and other natural resources management, it is possible to say that the current agricultural policies implemented in the region do not take into account the agro-environmental problems of the region and do not include agro-environmental policies. Current policies are found to primarily promote agricultural productivity, increased competitiveness, and regional integration of agricultural products and markets.

\subsection{West Africa's common environmental policy and agriculture}

Environmental degradation leads to soil degradation thus leading to the reduction and weakening of agricultural productivity, and consequently, food insecurity in rural and urban areas and the growth of poverty. For this reason, protecting the environment is essential for maintaining food security and achieving sustainable development. In this sense, to promote the well-being of the West African people, ECOWAS has developed a regional environmental policy for sustainable management and use of the environment and natural resources that today are in danger and full destruction. The ECOWAS environmental policy and the West African Economic and Monetary Union's (UEMOA) common policy for environmental improvement aims to create a healthy, viable and productive environment that contributes to improving the living conditions of the people in the region. To this end, measures have been taken to protect natural resources, reduce environmental degradation and reverse the tendency of the destruction of natural resources (ECOWAS, 2008). The second strategic intervention axis of this policy is closely linked to agriculture. As part of this intervention, the real causes of the destruction of the natural resources are addressed, as well as land degradation and desertification, conservation and sustainable management of natural resources and 
biodiversity (ECOWAS, 2008). In this axis, through an ecosystem approach, the focus has been on the contribution of the forest sector and forest products to the regional economy and sustainable integration (IUCN, 2008). In the implementation of the policy, there are two programs related to this axis and therefore related to agriculture. These are the regional vulnerability mitigation program in West Africa and the regional action program to combat desertification in West Africa and Chad. The first program aims to strengthen the region's flexibility and adaption capacity against climate change, while the second aims to establish a unifying framework to combat desertification, land degradation and drought in West Africa and Chad. Although these two operational instruments of West Africa's environmental policy have contributed significantly to the fight against the environmental problems caused by the agricultural sector, they remain insufficient to reduce and solve the environmental problems in the region. In addition to this, although this environmental policy covers various sectors causing environmental problems; when conducting general policy analysis, it can be argued that legal and economic intervention instruments and tools are not defined in the policy. Therefore, depending on the sectorial activities and their impacts on the environment, it is extremely important to identify the appropriate legal and economic intervention instruments to tackle environmental problems and protect the environment. With particular regard to the agricultural sector, agro-environmental policies and climate change measures need to be defined taking into account the real environmental problems of agriculture in the region countries.

\subsection{Recommendations}

Faced with the increasing food demand related to population growth and changes in dietary patterns, and in this context to achieve the required agricultural production; reducing or minimizing the environmental damage caused by agriculture is one of the essential conditions for sustainable food supply and sustainable development. This reduction or minimization of agro-environmental challenges is only possible with better agroecosystem management and use. Thus, as the causes of these environmental challenges are interacted and interrelated, the improvement of approach and implements of agro-environmental management must take into consideration this relationship, interaction between challenges and their interrelatedness. Therefore, environmental issues arising from agricultural production should be integrated into agricultural policies and environment-friendly agricultural production policies must be implemented in agricultural policies. As a result, the following recommendations have been made based on the abovementioned agro-environmental issues and the review, examination of current agricultural and environmental policies in the region. 
- Permanently monitor and evaluate the environmental performance of agriculture;

- Take into account agro-environmental indicators in agricultural statistics and also in the preparation, conception, and development of agricultural and environmental policies;

- Openly and clearly integrate the environmental dimension of agricultural production into agricultural policies;

- Specific and detailed integration of the agricultural dimension in environmental policies in a way (because it is a major user of natural resources in the region);

- Develop more specific and concise agro-environmental policy instruments including improved and suitable for agro-ecological characteristic of region (specifically of each country) approach of sustainable agro-environment management and climate-smart management of agroecosystem;

- Conduct agro-environmental training programs for farmers and producers (eco-friendly agricultural production techniques on issues such as agroenvironmental management in agriculture, farming or agribusiness; the importance of biodiversity);

- Encourage farmers to apply techniques and practices of sustainable land management, soil restoration, sustainable agriculture, ecological agriculture, and agroforestry; level;

- Improve the mechanisms for the biodiversity conservation at the farm

- Applying sustainable forest management policies to reduce deforestation and forest degradation;

- Define more incentive mechanisms to reduce greenhouse gas emissions from deforestation and forest resources destruction;

- Examine and carefully define sustainable fishing practices to be supported and fishing quotas in the region;

- Implement subsidies and support grant to farmers based on environmental ethics and protection;

- Establish soil microbiology laboratories and encourage advanced research in the field of soil microbiology;

- Strengthen regional, continental and global cooperation to combat the effects of global warming due to agriculture. 


\section{Conclusion}

Agricultural activity occupies an important place in the West African region. Despite the increasing demand for food, the conservation of natural resources used in agricultural production to ensure the continuity of food security is an inevitable subject of agricultural interventions. However, sustainable food supply and the sustainability of biodiversity are not possible without considering the negative effects of agriculture on the environment or other natural resources in agricultural interventions. Therefore, the West African countries' agro-environmental challenges examined in this study must be taken into account in the agricultural policies to be implemented as well as legal and economic intervention tools and instruments that must be defined also in agro-environmental policy design.

For the common policies implemented in West African countries to be successful, it is important to study the similarities or differences between the countries of the region in terms of problems and opportunities. Each country's priority and the severity of its problems may be different. The main agroenvironmental issues in West Africa $\mathrm{n}$ countries are deforestation, land degradation, water pollution, air pollution, climate change and degradation of agricultural biodiversity. Determining the extent of these problems in all West African countries is of great importance. To reduce the environmental problems of agriculture, encouraging the cultivation of products appropriate to the ecological characteristics of each country will contribute to the rational use of natural resources. In this context, vegetable and animal production areas should be identified and common intervention tools developed to minimize agroenvironmental problems caused by cotton production and livestock production, which are the main two major productions accentuating the degradation of agroecology in the region. The successful integration of agro-environmental policy into agricultural policies requires extensive and detailed environmental monitoring and effective policy evaluation. In addition to monitoring and evaluation, this success also depends on the careful determination of the agro-environment policy framework, context and its complete and correct implementation. Only in this way sustainable agricultural production and sustainable food security can be achieved through environmentally friendly production techniques by reducing the negative impacts of agriculture on the environment in West African countries.

References :

1. Abba, A. A., Hofs, J-L, Mergeai, G., (2006), Relever les défis environnementaux pour les filières cotonnières d'Afrique de l'Ouest et du Centre, Biotechnologie, Agronomie,
Société
et Environnement,
10
(4) : 351-359.

http://www.pressesagro.be/base/text/v10n4/351.pdf 
2. CEDEAO, (2004), La politique agricole de l'Afrique de l'Ouest (ECOWAP): Diagnostic, enjeux, questions clées et scénarios 2020. http://hubrural.org/IMG/pdf/cedeao ecowap presentation ppt.pdf.

3. CEDEAO, (2008), La politique environnementale de la CEDEAO. Direction de l'Environnement de la CEDEAO, Commission de la CEDEAO. https://events. ecowas.int/wp-content/uploads/2013/03/Environ-PUBLICATION-FRE-1.pdf.

4. CEDEAO, (2015), L'agriculture et l'alimentation en Afrique de l'Ouest : Mutations, Performances et Politiques agricoles. http://www.hubrural.org/IMG/pdf/LivretEcowap2014-fr-Light.pdf.

5. FAO, (2017), Strengthening sector policies for better food security and nutrition results; Climate change. http://www.fao.org/3/a-i7217e.pdf.

6. FAO, (2019), Agri-environmental Indicators. http://www.fao.org/faostat/fr/\#. Accessed 25 May 2019

7. FAO, (2019), FAOSTAT, Agri-environment indicators; Carbon in topsoil. http://fenixserices.fao.org/faostat/static/documents/ES/ES Carbon in topsoil e.pdf.

8. FAO, (2019), FAOSTAT, Agri-environmental indicators, Soil erosion/Land degradation. http://fenixservices.fao.org/faostat/static/documents/ES/ES_Soil_erosion_Land_degra dation e.pdf.

9. FAO, (2019), FAOSTAT. http://www.fao.org/faostat/fr/\#data. Accessed 25 May 2019

10. FAO \& IWMI, (2017), Water pollution from agriculture: a global review, Executive summary. http://www.fao.org/3/a-i7754e.pdf.

11. IPCC, (2019), Climate Change and Land. An IPCC special report on climate change, desertification, land degradation, sustainable land management, food security, and greenhouse gas fluxes in terrestrial ecosystems. The approved Summary for Policymakers. https://www.ipcc.ch/report/srccl/.

12. OCDE, (2008), La performance environnementale de l'agriculture dans les pays de l'OCDE depuis 1990. Paris: OCDE. https://www.oecd.org/fr/ue/40845405.pdf.

13. OCED, (2001,) İndicateurs environnementaux pour l'agriculture. Paris.

14. Parlakay, O., Çelik, A., Kızıltuğ, T., (2015), Hatay İlinde Tarımsal Üretimden Kaynaklanan Çevre Sorunları ve Çözüm Önerileri. Mustafa Kemal Üniversitesi Ziraat Fakültesi, 17-26. https://www.researchgate.net/publication/311304004_Hatay_Ilinde_ Tarimsal_Uretimden_Kaynaklanan_Cevre_Sorunlari_ve_Cozum_Onerileri.

15. RECA, (2019), http://www.reca-niger.org/spip.php?article-62. Accessed 25 May 2019

16. UEMOA, (2008), Acte additionnel N 01/2008/CCGE/UEMOA portant adoption de la politique commune d'amelioration de l'environnement. Commission UEMOA. http://www.droit-afrique.com/upload/doc/uemoa/UEMOA-Acte-additionnel-2008-01PCAE.pdf.

17. UICN, (2008), Politique environnementale de l'Afrique de l'Ouest. https:// www.iucn.org/sites/dev/files/content/documents/note politique environnement.pdf.

18. USAID, (2013), West Africa Environmental Threats and Opportunities Assessment. Final report.https://usaidgems.org/Documents/FAA\&Regs/FAA118119/WestAfrica2013.pd $\mathrm{f}$ 
19. Vergez, A., (2011), Intensifier l'agriculture en Afrique, réponse aux défis alimentaires environnementaux ? Afrique contemporaine 1 (237) : 29-43. https://www.cairn.info/revue-afrique-contemporaine-2011-1-page-29.htm.

20. Y1lmaz, H., (2005), Evaluation of Environmental Effects of Chemical Fertilizer Use in Terms of Economic and Environmental Perspective. Tebliğ, I. Çevre ve Ormancılık Şurası 21-24 Mart 2005, Antalya.

21. Yilmaz, H. 2018.Economic Analysis of Pesticides Management for Effective AgroEnvironmental Policy in Context of Sustainable Rural Development. Proceedings of The 10th International Workshop on Regional Innovation Studies (IWRIS2018), page :91-95

(C) 2020 by the authors. Licensee UAIC, Iasi, Romania. This article is an open access article distributed under the terms and conditions of the Creative Commons Attribution (CC BY-NC-ND) license (https:// creativecommons.org/licenses/by-nc-nd/4.0). 